\title{
Rates of Change in Oak Forest Distribution During the Last Deglaciation
}

\section{RAchid Cheddadi}

Centre Universitaire Arles, European Pollen Database CNRS - UMR 6116, 13200 Arles, France; rachid.cheddadi@univ.u-3mrs.fr

The distribution of plant species over continents changes drastically during climatic cycles. The range of temperate species in Europe has expanded and retreated several times during the last few climatic cycles. Mapping these ranges over a period of time (such as the last 15,000 years) helps visualize the distribution changes (oak map by Brewer et al., 2002, Fig. 1). However, time series are a more appropriate tool for estimation of the rapidity of these changes.

During the last glacial maximum, most temperate tree species survived the extremly cold and dry climate within a few limited areas known as refugia. In Europe, such refugial areas have been identified in Spain, Italy, Greece and the Balkans. They are localized in mountainous regions, usually with southern exposure, where sufficient moisture and warmth existed for plants to survive glacial periods. At the end of each glacial period, temperate trees migrate, with different rates, from their refugia to occupy more extensive areas. The same species do not necessarily survive in the same refugia from one glacial to another. A given species may propagate from it's refugium during an interglacial and not be able to return to it during the following glacial. Thus, it is difficult to compare the rates of distribution change over several climatic cycles for the same species.

Here we focus on the last deglaciation during which oak forests underwent dramatic changes in both population density and distributional range. Roughly, the deciduous oak started to migrate from its glacial refugia between 15 and 14,000 years $\mathrm{BP}$ and reached its northern climatic limit during the Holocene around 6000 years BP. During deglaciation, Oak forest "boundaries" moved at a maximum rate of approximately 100 km/century. Fossil pollen records provide quantitative information about the rates of change in oak

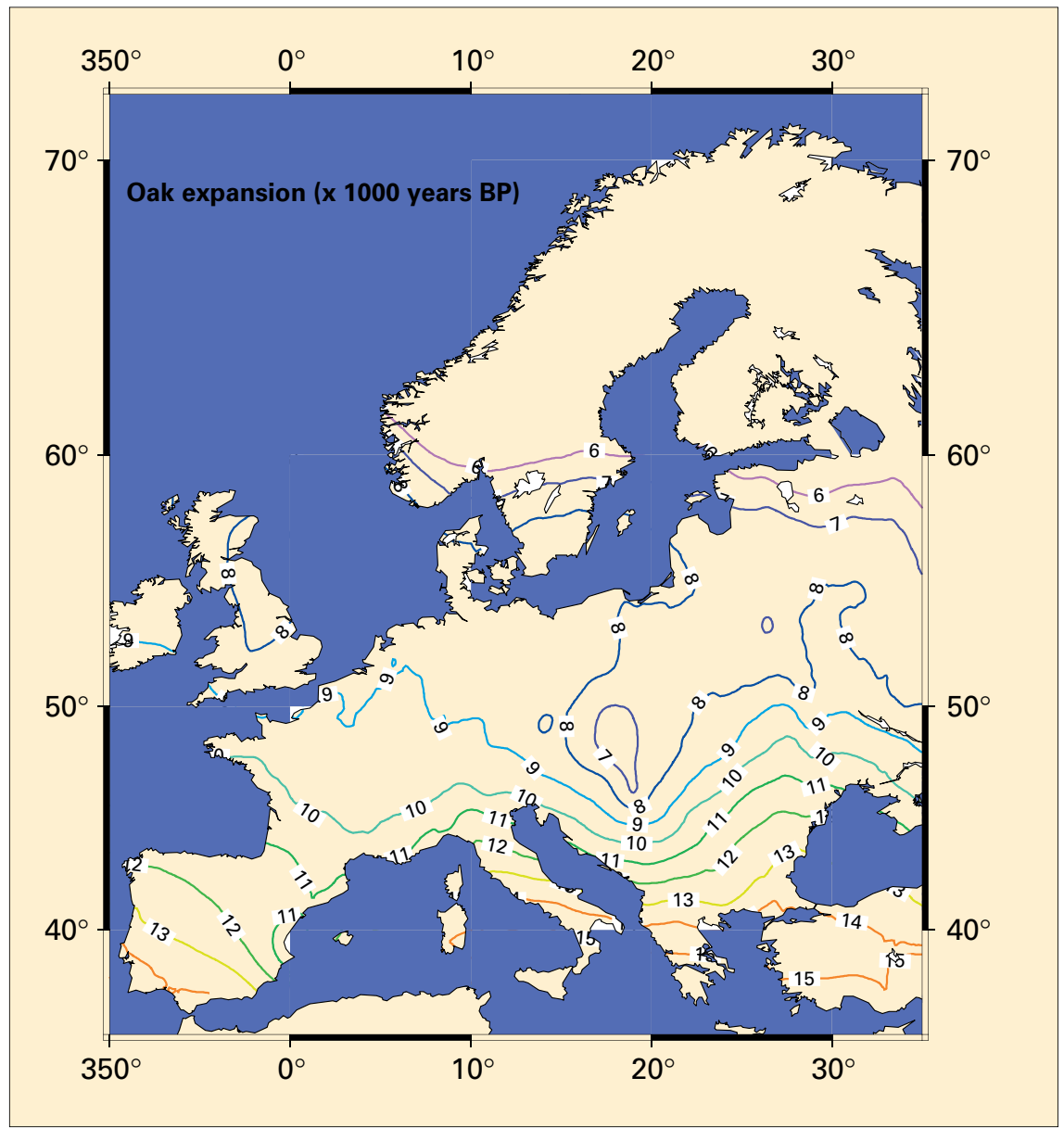

Fig. 1: Expansion of oak during the period between 15,000 and 6,000 years BP (Brewer et al., 2002)

forest distribution throughout this period of time. Jacobson et al. (1987) showed that the difference of the square root of pollen percentages over prescribed even time intervals provides a good measure of the rate of change in species prevalance in the landscape. Application of this method requires that paleo proxydata be interpolated onto an evenly time spaced scale whereas pollen records are often unevenly sampled and their chronological frame is based on a few ${ }^{14} \mathrm{C}$ dates. Lotter et al. (1992) pointed out that «rates of change [derived] from proxy-data are critically dependent on a reliable chronology". Such caution should be applied to reconstruction of any abrupt event, irrespective of proxy type, when the chronology is based on the ${ }^{14} \mathrm{C}$ time scale.
The comparison of the rates of change estimates from two sites with very different geographical locations relative to glacial refugia from which oak originated may be interesting. The Padul pollen record (southern Granada, Spain) is located in an area where a glacial refugium for deciduous oak has been identified. Lac Noir (Massif Central, France) on the other hand was surrounded by open vegetation where oak did not survive during the last glacial maximum. Genetic studies have shown that the deciduous oak now growing in France originated from the Iberian and the Italian peninsulas (Petit et al., 2002). The chronological time frame (Figs. 2 and 3) for the two pollen records indicate that there was 3000 year time lag required for the expansion of oak between the two sites. 


\section{Science Highlights}

The oak pollen percentages obtained from Lac Noir (Guenet and Reille,1988) and from Padul (Pons and Reille, 1988) illustrate the timing of both the distributional spread and the local expansion of the population (Figs. 2a, 3a). The overall rates of change at both sites (Figs. 2b, $3 b)$ indicate a great variability but show two distinctly different patterns in both timing and amplitude. The southern Padul record shows an early and abrupt change corresponding to the Bolling warming. Other peak rates of change are detected between 13 and 10,000 years $\mathrm{BP}$ in Padul. Although independent proxy data indicate that a succession of warm and cold climates were also recorded in France at this time, no change is observed at Lac Noir as oak had simply not yet reached the area. Only after 10,000 years BP did oak arrive in the Massif Central. It then expanded between 10 and 6,000 years BP and a decline is recorded afterward. The rate of change associated with the first expansion of oak (around 9,700 years BP) is the highest of the whole record. This first high rate of change at Lac Noir is lower than the first one at Padul. These differences might be explained by the fact that a change in the vegetation is more rapid and amplified when the landscape offers less competition with other species. On the other hand, the oak pollen percentages suggest a progressive pattern of colonization and the rates

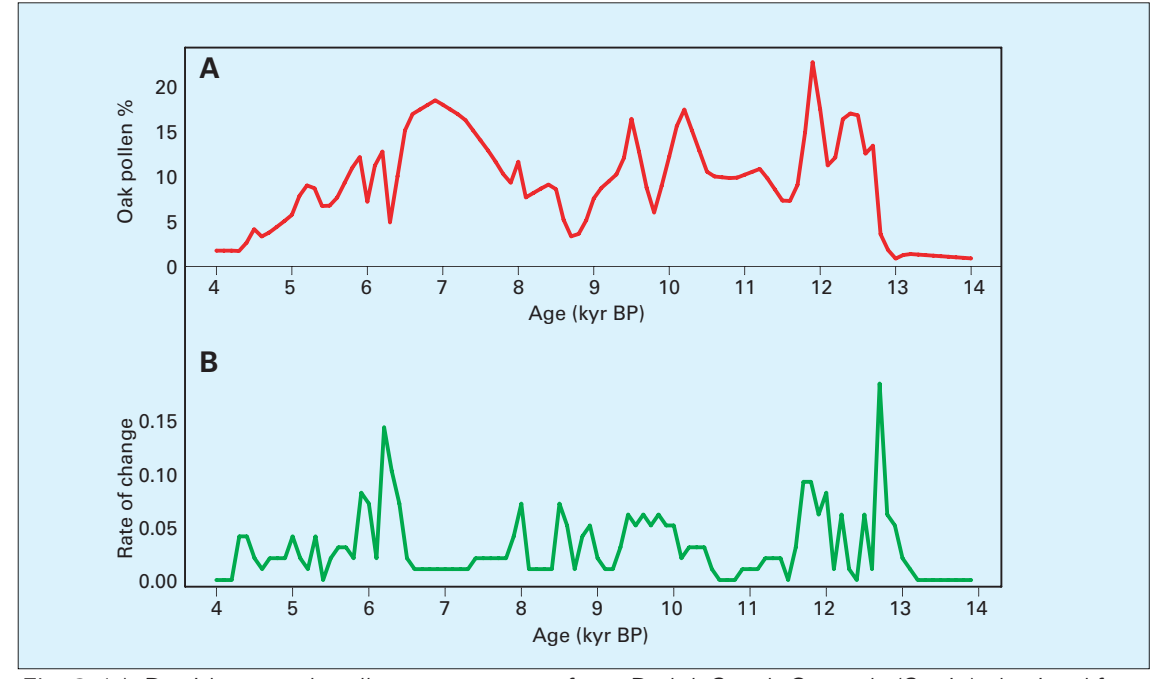

Fig. 3: (a). Deciduous oak pollen percentages from Padul, South Granada (Spain) obtained from the European Pollen Database www.ngdc.noaa.gov/paleo/epd/epd_main.html, contributed by M. Reille. (b). Rates of changes of deciduous oak at Padul. of change show a distinct succession of peaks which are less obvious in the Padul record. Such discrepancies may confirm more competition with other temperate species around Lac Noir than in Padul. The next highest peak of rate of change is recorded (more or less synchronously) at both Padul and Lac Noir at the beginning of an irreversible decline in oak populations between 6500 and 6000 years BP when the oak pollen percentages decrease steadily at both sites. This second high peak may indicate the response of oak to similar climatic change at both sites. These two pollen records had 7 to 8 times of rapid change during the warming which occured during postglacial period and therefore illustrate well how fast a temperate species such

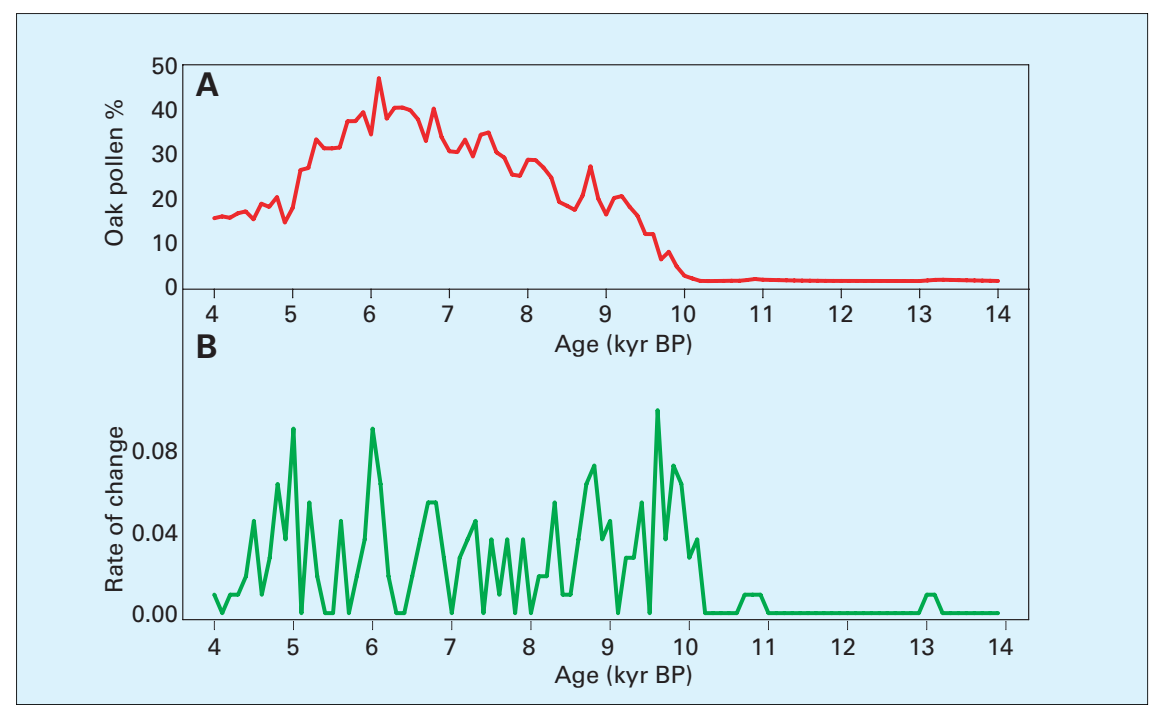

Fig. 2: (a). Deciduous oak Pollen percentages from Lac Noir, Massif Central (France) obtained from the European Pollen Database www.ngdc.noaa.gov/paleo/epd/epd_main.html, contributed by P. Guenet. (b). Rates of changes of deciduous oak at Lac Noir. as the deciduous oak, may respond to environmental changes. However, will temperate species overcome the greenhouse effect and the expected induced global warming during the next decades? Will all temperate species present in an ecosystem follow such abrupt changes? Although, the Oak case shows that a temperate tree species may adapt to rapid climate changes, the expected abruptness of the climate change may require more than the 7 or 8 time rapid change recorded during the deglaciation.

\section{REFERENCES}

Brewer, S., Cheddadi, R., Beaulieu, J.L. and Data contributors, 2002: The migration of deciduous Quercus throughout Europe since the last glacial period. Forest Ecology and Management, Vol. 156 (1-3), 27-48.

Guenet, P. and Reille, M., 1988: Analyse pollinique du lac-tourbière de Chambedaze (Massif Central, France) et datation de l'explosion des plus jeunes volcans d'Auvergne. Bulletin de l'association française pour l'étude du Quaternaire, 4, 175-194.

Jacobson, G.L.jr., Webb III, T., and Grimm, E.C., 1987 : Patterns and rates of vegetation change during the deglaciation of eastern north America. The Geology of North America. The Geological Society of America, vol. K-3, 277-287.

Lotter, A.F., Amman, B. and Sturm, M. 1992. Rates of change and chronological problems during the late-glacial period. Climate Dynamics, 6, 233-239.

Pons, A. and Reille, M., 1988: The holocene - and upper pleistocene pollen record from Padul (Granada, Spain): a new study. Palaeogeography, Palaeoclimatology, Palaeoecology, 66, 243-263.

Petit, R. J., Brewer, S., Bordacs, S.B., Burg, K., Cheddadi, R., et al., 2002: Postglacial colonisation routes of European white oaks inferred from the variation of chloroplast DNA and from the analysis of fossil pollen. Forest Ecology and Management, Vol. 156 (1-3), 49-74. 